\title{
University economists training under global educational environment: challenges and prospects
}

\author{
Nailya G. Bagautdinova ${ }^{1}$, Yuliya N. Gorelova ${ }^{1 a}$, and Oksana V. Polyakova ${ }^{1}$ \\ ${ }^{1}$ Kazan Federal University, 4, Butlerov st., Kazan, 420012, Russia
}

\begin{abstract}
Kazan Federal University being the leading one in the Volga region has set a strategic goal of academic reputation and University authority growth to achieve a high level of international recognition. The article describes the measures that were implemented by University management to enter the list of world leading universities. Some tools that accompany and foster necessary transformation are described and the way to align strategic priorities and economists training programs development is analyzed. The paper considers Bachelor and Master Degree courses in Economics and Management reshaping and establishes connection between New Third Generation Educational Standard introduction into the system of higher education and the process of University integration into the global educational environment. The new competence-based paradigm and interdisciplinary approach are both considered as important steps to improve academic and research performance. The "road map" developed and implemented by University management team was used as a platform for content analysis of qualitative data via systematic examination and verification of projected indicators open for public consideration on the official University web-page.
\end{abstract}

Keywords: University; higher education; academic reputation; competence; interdisciplinary approach; global educational environment; double-degree program; curriculum.

\section{Introduction}

Kazan Federal University being the leading one in the Volga region is distinguished by outstanding academic reputation in the field of research and development. Highly qualified training provided by University staff positions its graduates among the most in demand in the labor market. The academic education pivotal role nowadays is to train highly qualified specialists that are able to analyze the present state of the economy and to harness the

\footnotetext{
${ }^{a}$ Corresponding author: gorelovajuliya@gmail.com
} 
growing complexity of the economic environment under the influence of scientific, technological and social progress in post-industrial era.

The higher education system transformation started when Russian Federation signed the Declaration of the Bologna process in 2003. The shift from Specialist Degree to Bachelor Master Degree paradigm is considered to be a significant step towards European educational environment.

Globalization has penetrated into every aspect of human life and institutions of higher education are not excluded from this process. The recent trend in the field of higher education based on innovative approach covers all aspects of professional training: educational technology, learning and research integration based on market demand, informational support of the educational process, adequate procurement and highly qualified personnel that share the same values. The systematic generation of knowledge that enhances the capability to innovate places Kazan Federal University at the forefront of educational process. Modern economic development is characterized by high value of human capital which is considered to be national economic development main resource and requires large-scale investments.

The strategic goal of KFU is academic reputation growth and University authority in the field of research and development consolidation to achieve a high level of international recognition. The main vector of reforms was to create a corporate culture based on shared values through integrating and facilitating cooperation between various departments. It served as a platform for future transformations and the launch of its main drivers - centers of excellence.

The article describes the measures that were implemented by University management to achieve one of its main strategic goals - to enter the list of leading universities. Some tools that accompany and foster necessary transformation are described and the way to align strategic priorities and economists training programs development is analyzed. The paper considers Bachelor and Master Degree courses in Economics and Management reshaping and establishes connection between New Third Generation Educational Standard introduction into the system of higher education and the process of University integration into the global educational environment. The new competence-based paradigm and interdisciplinary approach are both considered as important steps to improve academic and research performance.

The "road map" developed and implemented by University management team was used as a platform for content analysis of qualitative data via systematic examination and verification of projected indicators open for public consideration on the official University web-page. The strategy implemented showed the growth of the University position in all key ratings. Therefore, there is a plan to distribute accumulated benefits to Humanities and Social Studies. Trajectory to achieve the selected target is described in the article and supported by a set of performance indicators.

\section{Internationalization of education}

Globalization has significant impact on educational process. The particular sensitive areas that are sometimes described as key indicators of university openness are students' and teaching staff mobility, number of double-degree programs provided by institutions, professors' publications and university ranking. Vocational and social mobility, ability to use information technologies, critical thinking and ability to make decisions are the characteristics of competent graduate. Cross-cultural competence formation and vocational training programs help students both at undergraduate and graduate level to increase participation in scholarships and international mobility programs, [6].. 
Globalization is inherent in innovations. Innovative process being an integral part of education affects all its spheres. Higher educational institutions are major players in educational market and nation's economy. As a result, they are forced to be at the cutting edge of innovation and tend to implement entrepreneurial approach to both education and research as in "knowledge-intensive service-based institutions" focus on quality and innovations is a primary success factor, [1].

The innovation process concerns university environment, management and educational paradigm as a whole. It involves reshaping degree-courses, introduction of competencebased learning, and European Credit Transfer System rank with computer-assisted learning, open learning, work-place learning, and lifelong learning. The new approach which is gaining popularity is the concept of flexible learning which adopts contingent approach to learning design and delivery [13]. It presupposes that entry requirements, learning strategies, technologies and assessment tools match backgrounds, abilities and experience of potential students taking into account learning outcomes, professional requirements and learning environment limitations, [13].

Driven by the process of internationalization described as one of the forces that influences and moulds the system of higher education worldwide, [9], institutions of higher education have to elaborate their sustainable development programs in accordance with this trend. Some obvious benefits associated with global education are the education quality improvement, academic mobility and research cooperation growth, transfer to knowledgebased economy and as a result better competitiveness [14]. The debate about borderless education revealed some unsolved issues: the number of foreign students and professors participating in double-degree programs is still insignificant, undergraduates and academics outflow outpaced inflow for the same period, credit accumulation system and modular approach to education are still not realized due to traditional subject-based system of education[4].

Academic mobility described as "the most visible aspect of internationalization of higher education spurred by globalization" [16] characterizes the openness of the university and its increase proves that the so called "road map" elaborated by University authorities to improve competitiveness is correct. Despite all the success the lack of adequate language competence is still an impediment. English language fluency is a prerequisite for internationalization and scientific collaboration. The majority of academic research is published in English and it is the language of knowledge generation and proliferation, [10]. English is also the language of double-degree programs intended to attract international students.

Another important characteristic of university openness is its recognition by international rankings. English-speaking countries pioneered this approach as a dominant mechanism to measure institutional performance for stakeholders and broader public evaluation. Although validity of ranking system derives from its objectivity based on international recognition of research publications by Thomson Reuters and Elsevier's Scopus databases it heavily reflects US model of higher education predomination and is biased towards English-language publications, [11]. Substantial research funds from government and other sources and English as the primary language for both education process and research considered as advantage in ranking placement, [2]. Despite all controversy around this issue ranking system should not be excluded from sustainable development program implemented by university management, [15].

To add international recognition to the university double-degree programs are introduced to stay attuned with the global expansion of higher education. The benefits of such programs are not limited by enhancing employability but also involve greater cultural awareness, communicative skills development and international exposure of the graduates , [3]. Double-degree programs facilitate collaboration between disciplines, enhance problem- 
solving methods of teaching, and stimulate graduates ability to solve issues connected with sustainability, [12]. Transdisciplinarity is also said to be the value added of these programs since flexible knowledge and transferable skills can contribute to the development of such social spheres that are extremely important.

\section{Results and discussion}

The institute of Management, Economics and Finance (IMEF) being a structural unit of Kazan Federal University (KFU) responded to the challenges set by the international educational environment integration following the principles of internationalization and enhancing academic reputation.

Due to the development of ICT (information and communication technology) and increased visibility of Kazan Federal University applicants from other countries could make an informed choice among the proposed academic programs. Fierce competition for applicants among HEIs in various countries as well as at the domestic educational market set a number of challenges for enrollment, though IMEF KFU has a vivid competitive advantage offering at least 12 Majors in Economics and Management and 16 graduate programs. Among the students enrolled to the undergraduate programs are mainly citizens of CIS countries; it is explained by the Russian language of learning. Thus, the main challenge is to introduce English-language undergraduate programs, as Russian still predominates due to restrictions set by middle and low secondary school leavers language proficiency. However applicants from the countries which KFU has identified as its target markets (Turkey, CIS countries, China, Mongolia and South-East Asia, Latin America, the Middle East and Africa) are provided with an opportunity to take a preparatory semester studying Russian language, to pass a test and to be admitted to the selected program on a competitive basis. The University elaborated a system of international students' recruitment which resulted in 48\% increase in their number from 2013 to 2014 (2,106 vs. 1,423 students, Table 1). Moreover the university is deeply involved in raising funds for providing financial support to international students in the form of grants from German Academic Exchange Service (DAAD), the EU Erasmus+ program, Tatarstan Algarysh program, and national programs in Turkey (Mevlana) and Kazakhstan (Bolashak) as well as programs sponsored by employers. Moreover, since 2014, according to the undergraduate programs curriculum the number of credits for ESP (English for Specific Purposes) has increased three fold that could probably lead to an increase in students' mobility indicators and in number of prospective applicants for international double-degree programs.

Establishing of a purely international environment for the students in the Institute is another initiative taken by the management and faculty. The main objective of the concept is to involve students in life-long learning by means of various academic interdisciplinary and extra-curricular activities where English and ESP (English for Specific Purposes) are used as a universal means of communication with counterparts. The ability to use foreign language is considered to be crucial for students' intellectual potential development and their intellectual abilities formation, [5].

Unlike undergraduate Master's degree programs possess more competitive advantages mainly due to the lack of language limitations as most of applicants are supposed to have high English language proficiency equivalent to TOEFL 80. The IMEF has chosen international double degree programs as the first step to internationalization of its programs and curriculum. Collaborative programs with partner universities (in Germany, Finland and Poland) most of which are of interdisciplinary nature are welcomed by both academics and policymakers as they provide conditions for the increase in academic mobility 
indicators and offer degrees of two different universities thus enhancing the employment prospects, [9]. The benefits seem obvious as a "double degree program awards two individual qualifications at equivalents levels upon completion of the collaborative programs requirements established by two partner institutions" [13]. The main challenge in establishing a double-degree program is the development of a joint curriculum or its adjustment, since the most significant difference is the number of subjects in the curriculum (Russian program courses typically outnumber partner university program disciplines) though this issue could be settled after thorough investigation into courses outline as Russian educators tend to take a more specific approach to curriculum structuring unlike a more a general one adopted internationally. The second challenge is credit transfer for the subjects studied by exchange students at sending universities since Russian education system tend to apply a bureaucratic approach to this issue but the problem could be solved by inserting an appropriate clause in the agreement between partner universities at the stage of its initiation. It is worth mentioning that currently only the third semester (which is an exchange term) is taught in English, though in the short term English is supposed to become the only language of instruction at double-degree programs thus making them truly international. The Institute is planning to enlarge the list of international partners, as well as to increase the number of professors participating in mobility programs as guest lecturers since it contributes to course reshaping and teaching style improvement as dealing with international students always requires a change in mentality.

Moreover, the University has developed a special recruitment program for international scholars, according to which the share of guest professors who come to KFU for research and teaching purposes should increase two fold by 2020 (from $12 \%$ to $20-25 \%$, Table 2). At the same time in-house training initiatives are widely introduced, including workshops provided by leading international experts in various fields.

Academic reputation enhancement as contributing to the promotion in the world university ratings is given a priority both at the university and institute levels. University academic reputation is determined by its visibility in the academic community. The latter is predicated upon research and publication achievement, as well as by participation in the top world conferences. In order to provide the incentive for publishing in Scopus and ISI indexed journal, a separate unit responsible for providing publication support to the staff was established along with a reward system for publication in journals with high impact factor. Due to proper motivation and direction the publication activity of the KFU researchers has increased nearly two times from 2010 to 2014, thus leading to the sharp growth of articles in journals indexed by such citation databases as Scopus and ISI Web of Knowledge, followed by the $50 \%$ rise in the number of citations (Table 3 ).

Along with participation in the leading world conferences the institute takes great effort to make the University a platform for arranging and hosting these events. This incentive is guided by the opportunities for enhancing the university image and promoting its research prospects. Moreover, if a university is a conference organizer, more research and teaching staff as well as graduate and postgraduate could participate in the event, thus establishing research connections with international colleagues.

Table 1. Number of international students in KFU (2011-2014)

\begin{tabular}{lllll}
\hline Year & 2011 & 2012 & 2013 & 2014 \\
\hline Total & 886 & 1010 & 1423 & 2106 \\
\hline
\end{tabular}


Table 2. Number of international academic staff in KFU (2011-2014)

\begin{tabular}{lllll}
\hline Year & 2011 & 2012 & 2013 & 2014 \\
\hline Total & 12 & 28 & 121 & 161 \\
\hline
\end{tabular}

Table 3. Number of Publications in Scopus and Web of Science per faculty member (2011-2015)

\begin{tabular}{llll}
\hline Year & $2011-2013$ & 2014 & 2015 \\
\hline Scopus & 1.09 & 1.57 & 1.95 \\
\hline Web of Science & 0.77 & 0.91 & 1.18
\end{tabular}

\section{Conclusion}

Globalization accelerates competition not only in the sphere of employment but in the education process itself. To guarantee sustainable development institutions of higher education have to make quick and prompt responses to changing environment. Institute of Management, Economics and Finance of Kazan Federal University has elaborated and implemented the internationalization strategy in order to stimulate University openness. The article proves the efficiency of the strategy chosen demonstrating key indicators steady growth.

Some challenges that are left unsolved are connected with greater collaboration with real sector of economy. The next stage in the University development will be connected with orientation to professional standards and including them in the educational process. The New Standards of Higher Education are learning centered and aimed to prepare graduates for new working environment [8]. To support this process, the Institute held a series of round tables with industries' and educational authorities' representatives to develop a new standard of education which will be given a name "Educational Standards of the Third-Plus Generation".

The other important trajectory for the University development is associated with global trend of education humanitarization when human civilization experience in terms of values will build global thinking. It will help to achieve the ultimate objective of education lifelong learning process. The integrated policy of the University development should be oriented to provide a balance between progress, intelligence and moral perfection of the personality trained, [7]. The benefits of such integrated approach to education should be equally perceived by all stakeholder groups: from government officials to employers, and from undergraduates to their parents.

\section{References}

1. Achcaoucaou, F. et al., Competence Assessment in Higher Education: A Dynamic Approach. Human Factors and Ergonomics in Manufacturing \& Service Industries, 24 (4), 454-467, (2014).

2. Altbach, P. et al., Trends in global higher education: Taking an academic revolution. Rotterdam: Sense Publishers, (2010).

3. Culver, S. et al., Collaborative Dual-Degree Programs and Value Added for Students: Lessons Learned Through the Evaluate-E project. Journal of Studies in International Education, 16 (1), 40-61, (2012).

4. Dobren'Kova, E., Problems of Russia's Entry into the Bologna Process. Russian Education and Society, 50 (4), 42-51, (2008). 
5. Galishnikova, E., Language Learning Motivation: A Look at the Additional Program. Procedia - Social and Behavioral Sciences, 152, 1137-1142, (2014).

6. Gorelova, J., Advertising Language as a Means of Forming Students' Cross-cultural Competence. Procedia - Social and Behavioral Sciences, 152, 668-672, (2014).

7. Grigorieva, E., Language Teaching Content Renovation in the Context of Higher Education Internationalization. Procedia - Social and Behavioral Sciences, 152, $1143-$ 1147, (2014).

8. Ismagilova, L., \& Polyakova, O., The Problem of the Syllabus Design within the Competence Approach based on the Course "English for Master Degree Students in Economics (Advanced Level)". Procedia - Social and Behavioral Sciences, 152, 10951100, (2014).

9. Knight, J., Higher education in turmoil: the changing world of internationalization. Rotterdam: Publishers, (2008).

10. Lillis, T., \& Curry, M. J., Academic writing in a global context: The politics and practices of publishing in English. London: Routledge, (2010).

11. Ordorika, I., \& Lloyd, M., International rankings and the contest for university hegemony. Journal of Education Policy, 30 (3), 385-405, (2015).

12. Russell, W. A. et al., Double degrees: double the trouble or twice the return? Higher Education, 55, 575-591, (2008).

13. Scott, G., The Effective Management and Evaluation of Flexible Learning Innovations in Higher Education. Innovations in Education \& Training International, 33 (4), 154170, (1996).

14. Telegina, G., \& Schwengel, H., The Bologna Process: perspectives and implications for the Russian university. European Journal of Education, 47 (1), 37-49, (2012).

15. Wildavsky, B., The great brain race: how global universities are reshaping the world. Princeton/Oxford: Princeton University Press, (2010).

16. Yao Sua Tan, \& Soo Khoon Goh, International students, academic publications and world university rankings: the impact of globalization and responses of a Malaysian public university. Higher Education, (68), 489-502, (2014). 